\title{
The Morphometric Analysis of the Important Bone Structures on Skull Base in Living Individuals with Multidetector Computed Tomography
}

\author{
Análisis Morfométrico de las Estructuras Óseas Importantes en Base de \\ Cráneo de Sujetos Vivos Mediante Tomografía Computarizada Multidetector
}

Cihan Gökce*; Aynur Emine Cicekcibasi"*; Mehmet Tugrul Yılmaz ${ }^{* *}$ \& Demet Kıresi****

GÖKCE, C.; CICEKCIBASI, A. E.; YILMAZ, M. T. \& KIRESI, D. The morphometric analysis of the important bone structures on skull base in living individuals with multidetector computed tomography. Int. J. Morphol., 32(3):812-821, 2014.

SUMMARY: In this study, it was aimed to determine the reliable morphometric data of the important bone structures on skull base using MDCT and to establish the differences of these data according to sex and lateralization. This study was retrospectively carried out on MDCT images in the Radiology Department of Meram Medical Faculty, Necmettin Erbakan University. We evaluated the images of the 100 (male 50 - female 50) adult subjects without cranial trauma, surgery, and any deformity of the bone. The height and anteroposterior diameter of the hypophysial fossa $\left(\mathrm{HF}_{\text {height }}, \mathrm{HF}_{\text {anteropsterior }}\right)$, the length of the occipital condylus, anterior and posterior intercondylar distances (OCn, AID, PID); sagittal diameter, transverse diameter and area of the foramen magnum (FMsgt, FMtrn, FMarea) were all measured. The statistical analysis was performed using the SPSS. The summary of the data was expressed as mean \pm standard deviation. Student's t test was used to compare the male-female and right-left measurements. The relation betweeen parameters was evaluated by Pearson's correlation test. It was observed that right and left data in all parameters were higher in males than females. Higher values were usually determined on the right side in both sexes. In both sexes, some parameters were highly correlated $(\mathrm{P}<0.001)$. We believe that the results of this study may be useful for new surgical approaches and radiological assessment concerning skull base.

KEY WORDS: Skull base; Foramen; Canal; Morphometry; Multidetector computed tomography.

\section{INTRODUCTION}

Anatomical studies are based on morphometric measurement of the structures in the human body and their relationship with each other. A significant contribution is provided to other disciplines in medicine, because of the determination of anatomical measurements.

Many factors such as ethnicity, sex, age, and diet is effective for development. The parts of human skeleton have different anthropometric data according to sex and race (Schwaber et al., 1990; D'Aloisio \& PangrazioKulbersh, 1992; Villavicencio et al., 2001; Ulug et al., 2005; Barut et al., 2009). The skull base is a very important region of the skeleton because of the implementation of neurosurgical approaches and entries of vital structures (vessels - nerves). Many surgical approaches were described, such as anterior, anterolateral, lateral, posterolateral for skull base surgery (Cornu et al., 1990; George \& Lot, 1995). Both good anatomical knowledge and surgical experience are required to obtain successful results of these approaches (Ulug et al.). In addition, orientation during surgery is difficult because of the complex structure of the skull base. Orientation of the depth structures with surface anatomical landmarks is very important in planning surgical approaches. In the region, any injury can lead to postoperative neurologic morbidity and mortality, as well as intraoperative complications.

Dry bones, cadavers, and radiographic images were used at morphometric studies related to the morphometric measurements of skull base structures and surgical importance (Schwaber et al.; D'Aloisio \& PangrazioKulbersh; Villavicencio et al.; Ulug et al.; Turhan-Haktanir

\footnotetext{
* Terapi Dünyas1 Special Education and Rehabilitation Center, Konya, Turkey.

** Department of Anatomy, Meram Medical Faculty, Necmettin Erbakan University, Konya, Turkey.

**** Department of Radiology, Meram Medical Faculty, Necmettin Erbakan University, Konya, Turkey.
} 
et al., 2008). Multidetector computed tomography (MDCT) is the most advanced radiological imaging technique of the 21 st. century. MDCT is new, powerful, reliable, and noninvasive technique with which unique anatomical details can be obtained (Prokop, 2000). MDCT is a technique which can reveal the details of bone formations and provide excellent facilities for surgeons with high resolution and multislice images. In recent years, it was also used to obtain reliable morphometric data in anatomical studies (TurhanHaktanir et al.).

Measurement of various bone formations of the skull base has attracted the interest of anatomists, radiologists, surgeons, and anthropologists for many decades, viewing them in a clearly descriptive manner. In this study, we aimed to determine the reliable morphometric data of important bone structures of the skull base in living individuals which were necessary for many surgical approaches and to identify the differences of these data according to sex and lateralization. Moreover, there was no relevant anatomic study which viewing skull base via MDCT in the literature.

\section{MATERIAL AND METHOD}

This retrospective study was created on MDCT images of patients with acute nontraumatic subarachnoid hemorrhage or suspected cerebral aneurysm with symptoms such as headache, cranial neuropathy with non-contrast CT in the Radiology Department of Meram Medical Faculty, Necmettin Erbakan University, Konya, Turkey. Images of 100 adult individuals (50 males and 50 females) without cranial trauma, surgery or any bone deformity were examined.

All MDCT examinations were performed with a 64channel MDCT scanner (Somatom Sensation 64, Siemens, Germany). The images were obtained from patients in an optimal neutral head position without rotation, flexion or extension in order to provide standardized measurements. The images were retrieved to the Leonardoworkstation (Siemens Medical Solutions) and then were reformatted with $3 \mathrm{D}$ reconstruction. All measurements were made by visual estimation of the determined points at an approximate window setting and a level setting. Dimensions were measured using multiplanar reconstruction and 3D volume-rendered images. For accuracy, dot cursors for measuring on the $3 \mathrm{D}$ volumerendered image were placed in identical portions on corresponding axial, and sagittal images using rotation and translation of the reconstructed image. The distances were measured on the axial image passing from the points established on the level of sagittal image. For the axial measurements, the reviewers scrolled through the axial image to select the optimal location to measure diameter. The starting and ending points of distance for linear measurement on the axial images were determined with the internal digital caliper of the workstation. The software (syngommwp VE 30A, syngo VE32B) calculated all measurements and they were recorded in millimeters.

\section{The determined parameters on the internal skull base.}

The following parameters for internal skull base were evaluated according to midline reference points [frontal crest (FC), foramen caecum (FCM), anterior margin (FMAM) and posterior margin (FMPM) of the foramen magnum]. The evaluated parameters were listed.

1. The anteroposterior length of the hypophysial fossa $\left(\mathrm{HF}_{\text {anteroposterior }}\right)$ (Fig. 1).

2. The height of the hypophysial fossa $\left(\mathrm{HF}_{\text {height }}\right)$ (Fig. 1).

3 . The distance between the tuberculum sellae and foramen caecum (TS - FC) (Fig. 2).

4. The distance between the tuberculum sellae and prechiasmatic sulcus (TS - PCS) (Fig. 2).

5. The distance between the tuberculum sellae and dorsum sellae (TS - DS) (Fig. 2).

6. The distance between the dorsum sellae and the anterior margin of foramen magnum (DS - FMAM) (clivus) (Fig. 1).

7. The distance from the right and left optic canal to the midline $\left(\mathrm{OC}_{\text {right }}, \mathrm{OC}_{\text {left }}\right)$ (Fig. 3).

8. The distance between the right and left anterior clinoid processus (ACP) (Fig. 3).

9. The distance from the right and left foramen rotundum to the midline $\left(\mathrm{FR}_{\text {right }}, \mathrm{FR}_{\text {left }}\right)$ (Fig. 3).

10. The distance from the right and left foramen ovale to the midline $\left(\mathrm{FO}_{\text {right }}, \mathrm{FO}_{\text {left }}\right)$ (Fig. 3).

11. The distance from the right and left foramen spinosum to the midline $\left(\mathrm{FS}_{\text {right }}, \mathrm{FS}_{\text {left }}\right.$ ) (Fig. 3).

12. The distance from the right and left carotid canal to the midline $\left(\mathrm{CC}_{\text {right }}, \mathrm{CC}_{\text {left }}\right)$ (Fig. 3).

13. The distance between the right and left porus acusticus internus (PAI) (Fig. 3).

14. The distance from the right and left foramen jugulare to the midline $\left(\mathrm{FJ}_{\text {right }}, \mathrm{FJ}_{\text {left }}\right)$ (Fig. 3).

15. The distance between the right and left canalis nervi hypoglossi (CNH) (Fig. 4).

\section{The determined parameters on the external skull base.}

The following parameters on the external skull base were evaluated according to the midline reference points [mental symphysis (MS), posterior nasal spine (PNS), ante 


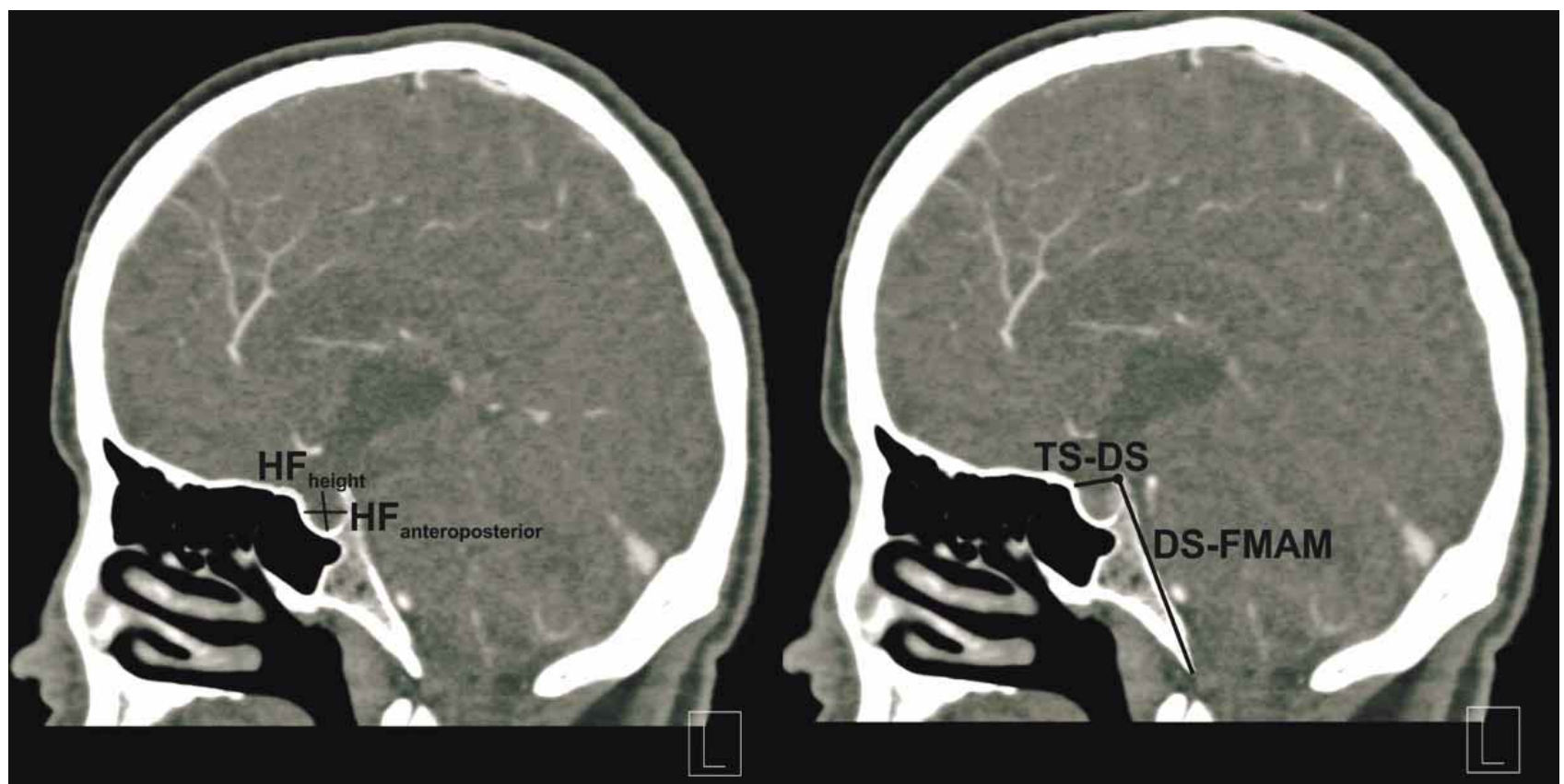

Fig. 1. The distance between the tuberculum sellae and dorsum sellae (TS-DS), the distance between the dorsum sellae and the anterior margin of foramen magnum (DS-FMAM) (clivus), the anteroposterior length of the hypophysial fossa (HF hypophysial fossa $\left(\mathrm{HF}_{\text {height }}\right)$.

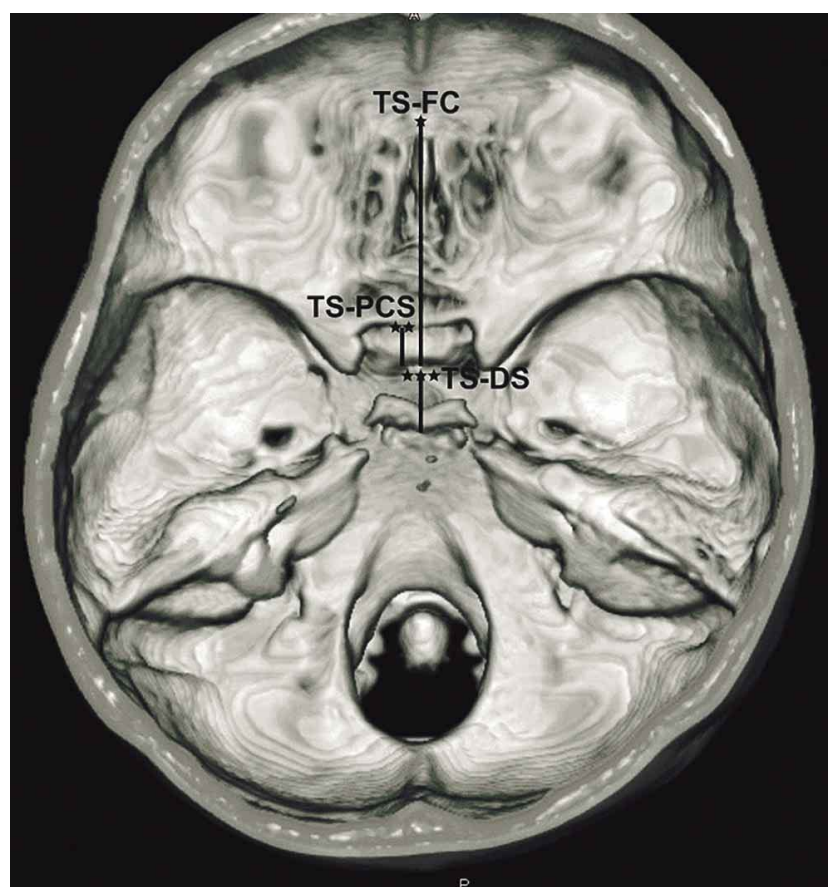

Fig. 2. The distance between the tuberculum sellae and foramen caecum* (TS - FC), the distance between the tuberculum sellae and prechiasmatic sulcus** (TS - PCS), the distance between the tuberculum sellae and dorsum sellae*** (TS-DS).

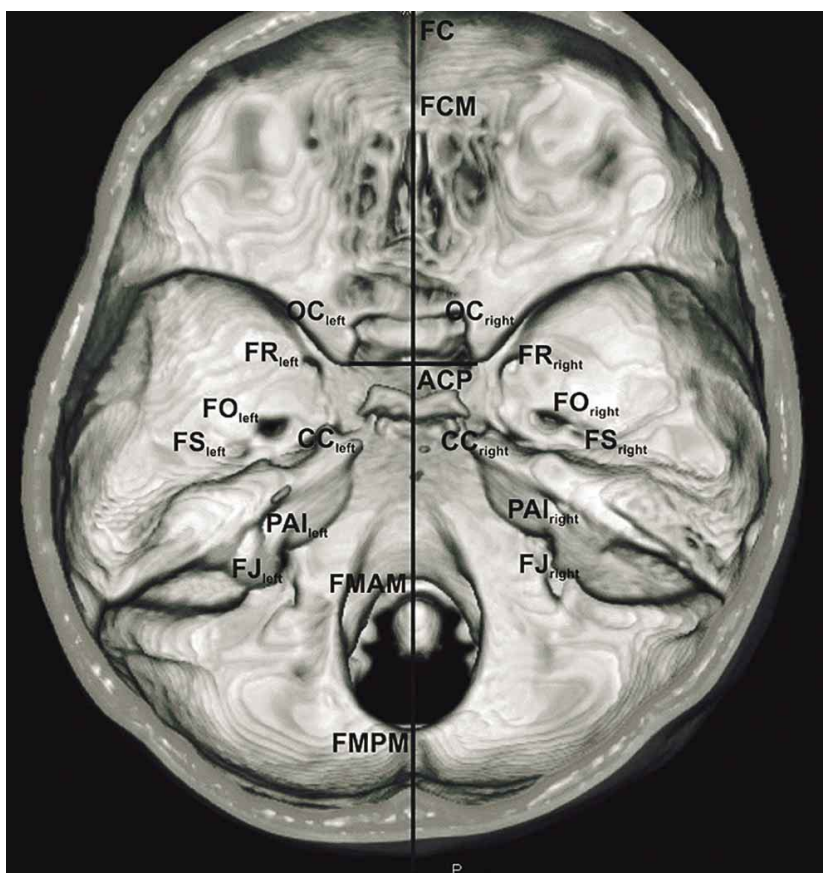

Fig. 3. The midline reference points on the internal skull base [frontal crest (FC), foramen caecum (FCM), anterior margin (FMAM) and posterior margin (FMPM) of the foramen magnum]. The distances from the right and left optic canal (OC), anterior clinoid process (ACP), foramen rotundum (FR), foramen ovale (FO), foramen spinosum (FS), carotid canal (CC), porus acusticus internus (PAI), foramen jugulare $(\mathrm{FJ})$ to the midline. 


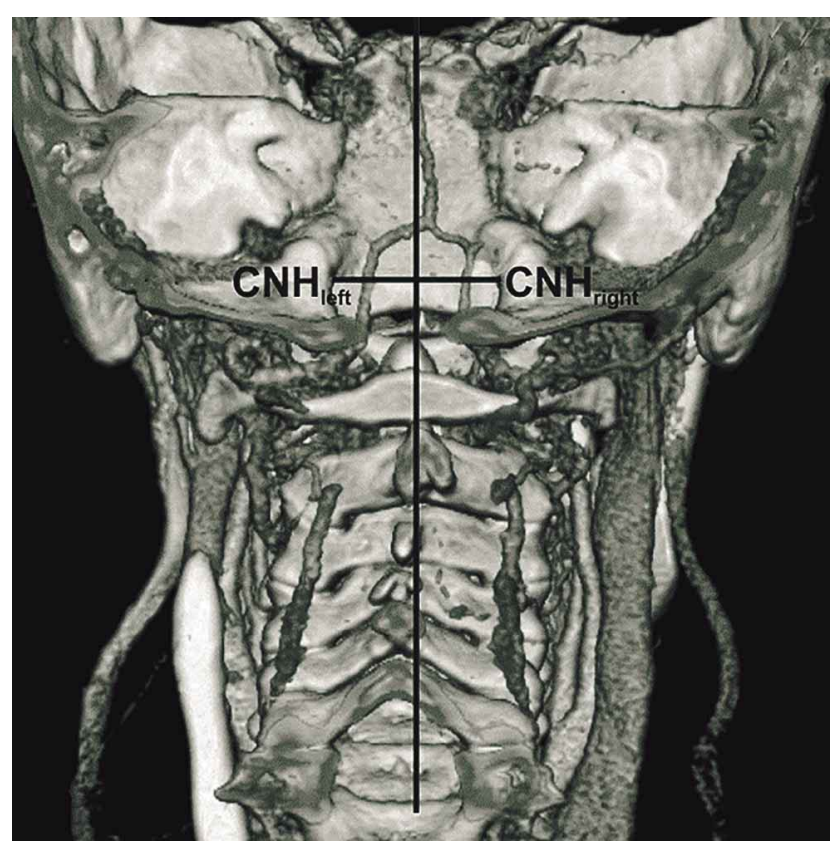

Fig. 4. The distance between the right and left canalis nervi hypoglossi $(\mathrm{CNH})$.

rior margin (FMAM) and posterior margin (FMPM) of the foramen magnum] (Fig. 5). The evaluated parameters were listed.

1. The lenght of the right and left occipital condyles $\left(\mathrm{OCn}_{\text {right }}\right.$, $\mathrm{OCn}_{\text {left }}$ ) (Fig. 6).

2. The anterior intercondylar distance (AID) (Fig. 6).

3. The posterior intercondylar distance (PID) (Fig. 6).

4. The sagittal diameter of foramen magnum $\left(\mathrm{FM}_{\text {sgt }}\right)$ (Fig. 7).

5. The transvers diameter of foramen magnum $\left(\mathrm{FM}_{\mathrm{trm}}\right)$ (Fig. 7).

6. The area of foramen magnum $\left(\mathrm{FM}_{\text {area }}\right)$ (Fig. 7).

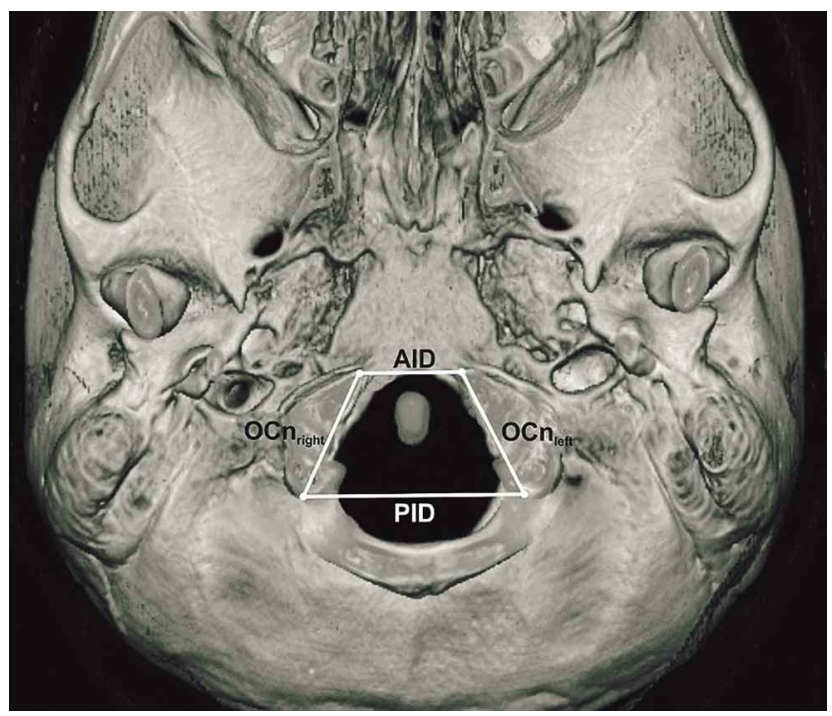

Fig. 6. The lenght of the right and left occipital condyles $\left(\mathrm{OCn}_{\text {right }}\right.$, $\mathrm{OCn}_{\text {left }}$, the anterior and posterior intercondylar distance (AID) (PID).

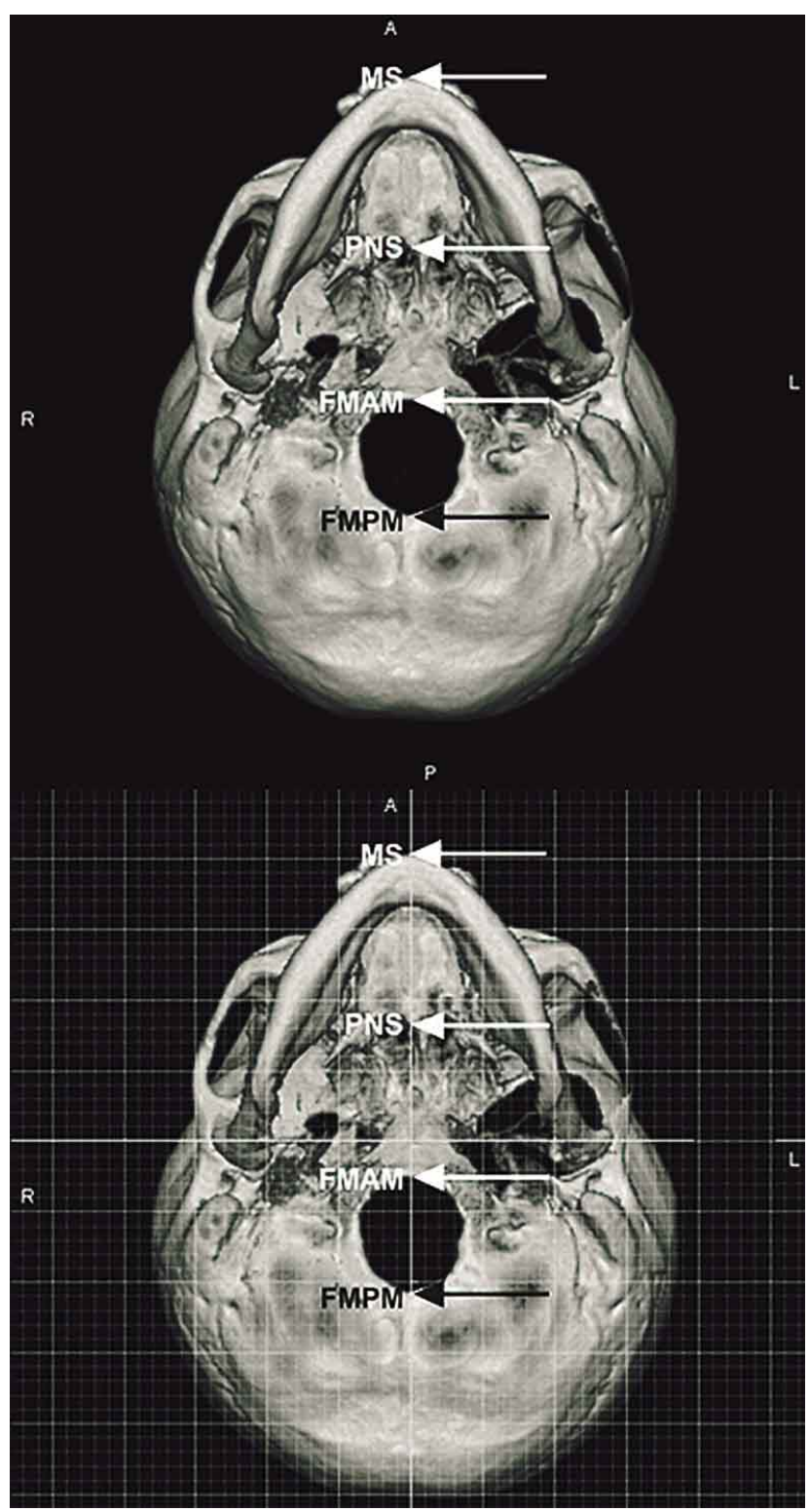

Fig. 5. The midline reference points on the external skull base [mental symphysis (MS), posterior nasal spine (PNS), anterior margin (FMAM) and posterior margin (FMPM) of the foramen magnum.

The statistical analysis was performed using the Statistical Package for the Social Sciences for Windows, version 13.0 (SPSS, Chicago, IL, USA). Sex comparison and the differences between the right and left measurement values were performed by the Student t test. Pearson's correlations were used to confirm the relationship between the variables. Statistical significance was defined as $\mathrm{P}<0.05$. This study conformed to Helsinki Declaration. 


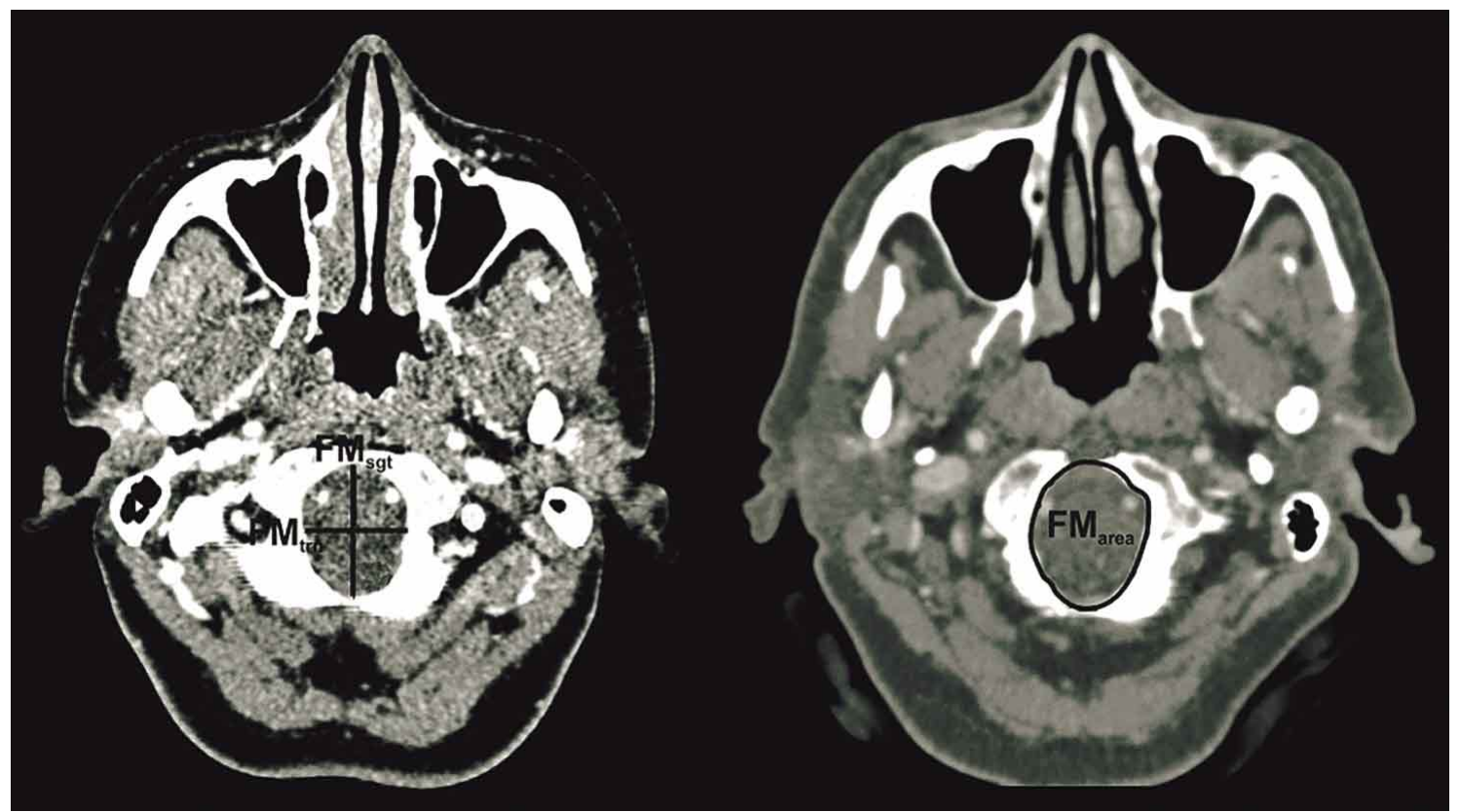

Fig. 7. The sagittal and transvers diameter of foramen magnum $\left(\mathrm{FM}^{\mathrm{sgt}}\right)\left(\mathrm{FM}_{\mathrm{trn}}\right)$, the area of foramen magnum $\left(\mathrm{FM}_{\mathrm{area}}\right)$.

\section{RESULTS}

The evaluation of the obtained data according to sex.

The significant differences were found FR, FO, FS, FJ, OCn, between the sexes $(\mathrm{P}<0.05)$ (Table I). In males, all data were higher than females.

The significant differences were determined DS FMAM, ACP, PAI, CNH, FM sgt AID, PID, FM trn $_{\text {area }}$, and the data were higher in males $(\mathrm{P}<0.05)$ (Table II). No significant differences were found in the other measurements $(\mathrm{P}>0.05)$.

In males, the evaluation of the obtained data according to lateralization. In males, the significant differences were detected the right and left FO, FS according to lateralization $(\mathrm{P}<0.05)$. The other data except $\mathrm{OCn}$ were higher in right side (Table III).

In females, the evaluation of the obtained data according to lateralization. In females, the significant differences were observed the right and left OC, FO, FS, CC, FJ according to lateralization $(\mathrm{P}<0.05)$. The other data except $\mathrm{OCn}$ were higher in right side (Table IV).

The evaluation of the obtained data according to correlation

The correlation was highly found between all data both sexes $(\mathrm{P}<0.001)$ (Tables $\mathrm{V}$ and $\mathrm{VI})$. In males and females, the positive correlation was found between the following data:

Table I. The right and left comparisons of the obtained data according to sex (Mean $\pm \mathrm{SD}, \mathrm{mm}$ ).

\begin{tabular}{lcccccc}
\hline \multirow{2}{*}{ Parameters } & \multicolumn{2}{c}{ Right } & \multicolumn{3}{c}{ Left } \\
\cline { 2 - 7 } & $\begin{array}{c}\text { Male } \\
(\mathbf{n = 5 0})\end{array}$ & $\begin{array}{c}\text { Female } \\
(\mathbf{n = 5 0})\end{array}$ & $\mathbf{P}$ & $\begin{array}{c}\text { Male } \\
(\mathbf{n = 5 5})\end{array}$ & $\begin{array}{c}\text { Female } \\
(\mathbf{n = 5 5})\end{array}$ & $\mathbf{P}$ \\
\hline OC & $9.5 \pm 1.6$ & $9.4 \pm 1.7$ & 0.715 & $8.9 \pm 1.8$ & $8.6 \pm 1.7$ & 0.494 \\
FR & $19.4 \pm 2.0$ & $17.9 \pm 1.7$ & $\mathbf{0 . 0 0 0}$ & $18.8 \pm 1.8$ & $17.5 \pm 1.7$ & $\mathbf{0 . 0 0 1}$ \\
FO & $23.5 \pm 1.7$ & $22.6 \pm 1.9$ & $\mathbf{0 . 0 1 3}$ & $22.6 \pm 2.0$ & $21.7 \pm 1.7$ & $\mathbf{0 . 0 1 2}$ \\
FS & $32.3 \pm 2.1$ & $30.9 \pm 2.3$ & $\mathbf{0 . 0 0 3}$ & $30.6 \pm 2.3$ & $29.5 \pm 1.9$ & $\mathbf{0 . 0 1 5}$ \\
CC & $9.1 \pm 1.2$ & $9.1 \pm 1.2$ & 0.896 & $9.0 \pm 1.4$ & $8.5 \pm 1.1$ & 0.069 \\
FJ & $26.3 \pm 2.3$ & $24.5 \pm 1.9$ & $\mathbf{0 . 0 0 0}$ & $25.3 \pm 2.9$ & $23.0 \pm 2.0$ & $\mathbf{0 . 0 0 0}$ \\
OCn & $24.5 \pm 2.5$ & $22.4 \pm 2.1$ & $\mathbf{0 . 0 0 0}$ & $24.6 \pm 2.7$ & $22.5 \pm 2.1$ & $\mathbf{0 . 0 0 0}$ \\
\hline$(\mathrm{P}<0.05)$ & & & & & &
\end{tabular}


1. Between $\mathrm{FM}_{\text {sgt }}$ and $\mathrm{HF}_{\text {anteroposterior }}, \mathrm{FM}_{\text {area }}, \mathrm{FM}_{\text {trn }}$

2. Between $\mathrm{FM}_{\text {area }}$ and $\mathrm{HF}_{\text {anteroposterior }}$

3. Between $\mathrm{HF}_{\text {height }}$ and $\mathrm{HF}_{\text {a }}$

4. In males, between FMt ${ }_{\text {trn }}$ and FM

5. In females, between $\mathrm{FM}_{\mathrm{trn}}$ and $\mathrm{HF}_{\text {anteroposterior }}, \mathrm{FM}_{\text {area }}$

Table II. The comparisons of the obtained data according to sex (Mean \pm SD, mm).

\begin{tabular}{lccc}
\hline Parameters & $\begin{array}{c}\text { Male } \\
(\mathbf{n}=\mathbf{5 0})\end{array}$ & $\begin{array}{c}\text { Female } \\
(\mathbf{n}=\mathbf{5 0})\end{array}$ & $\mathbf{P}$ \\
\hline $\mathbf{H F}_{\text {an }_{\text {teroposterior }}}$ & $10.1 \pm 1.4$ & $10.2 \pm 1.9$ & 0.749 \\
$\mathbf{H F}_{\mathrm{h}_{\text {eight }}}$ & $9.3 \pm 1.2$ & $9.5 \pm 1.0$ & 0.520 \\
TS - FC & $47.5 \pm 3.9$ & $46.9 \pm 3.3$ & 0.482 \\
TS - PCS & $8.7 \pm 1.8$ & $8.3 \pm 2.2$ & 0.327 \\
TS - DS & $10.7 \pm 1.4$ & $10.2 \pm 1.4$ & 0.098 \\
DS - FM & $49.2 \pm 2.7$ & $46.4 \pm 2.8$ & $\mathbf{0 . 0 0 0}$ \\
ACP & $27.3 \pm 2.3$ & $25.6 \pm 2.8$ & $\mathbf{0 . 0 0 1}$ \\
PAI & $48.2 \pm 3.5$ & $45.8 \pm 3.6$ & $\mathbf{0 . 0 0 1}$ \\
CNH & $28.6 \pm 2.5$ & $27.2 \pm 2.3$ & $\mathbf{0 . 0 0 3}$ \\
AID & $19.0 \pm 2.5$ & $17.7 \pm 2.8$ & $\mathbf{0 . 0 2 5}$ \\
PID & $40.5 \pm 3.1$ & $39.1 \pm 3.3$ & $\mathbf{0 . 0 3 0}$ \\
FM & $36.8 \pm 3.3$ & $34.6 \pm 3.6$ & $\mathbf{0 . 0 0 3}$ \\
FM $_{\text {trn }}$ & $30.9 \pm 2.6$ & $29.7 \pm 2.9$ & $\mathbf{0 . 0 4 1}$ \\
FM $_{\text {area }}$ & $86.1 \pm 3.3$ & $77.0 \pm 5.2$ & $\mathbf{0 . 0 0 2}$ \\
\hline
\end{tabular}

$(\mathrm{P}<0.05)$

Table III. In males, the comparisons the obtained data according to lateralization (Mean $\pm \mathrm{SD}, \mathrm{mm}$ ).

\begin{tabular}{lccc}
\hline \multirow{2}{*}{ Parameters } & \multicolumn{2}{c}{$\begin{array}{c}\text { Male } \\
(\mathbf{n = 5 0})\end{array}$} & \multirow{2}{*}{ P } \\
\cline { 2 - 3 } & Right & Left & \\
\hline OC & $9.5 \pm 1.6$ & $8.9 \pm 1.8$ & 0.098 \\
F R & $19.4 \pm 2.0$ & $18.8 \pm 1.8$ & 0.160 \\
FO & $23.5 \pm 1.7$ & $22.6 \pm 2.0$ & $\mathbf{0 . 0 3 0}$ \\
FS & $32.3 \pm 2.1$ & $30.6 \pm 2.3$ & $\mathbf{0 . 0 0 0}$ \\
CC & $9.1 \pm 1.2$ & $9.0 \pm 1.4$ & 0.582 \\
FJ & $26.3 \pm 2.3$ & $25.3 \pm 2.9$ & 0.073 \\
OCn & $24.5 \pm 2.5$ & $24.6 \pm 2.7$ & 0.325 \\
\hline
\end{tabular}

Table IV. In females, the comparison the obtained data according to lateralization (Mean $\pm \mathrm{SD}, \mathrm{mm}$ ).

\begin{tabular}{lccc}
\hline \multirow{3}{*}{ Parameters } & \multicolumn{2}{c}{$\begin{array}{c}\text { Female } \\
(\mathbf{n = 5 0})\end{array}$} & \multirow{2}{*}{ P } \\
\cline { 2 - 3 } & Right & Left & \\
\hline OC & $9.4 \pm 1.7$ & $8.6 \pm 1.7$ & $\mathbf{0 . 0 4 4}$ \\
FR & $17.9 \pm 1.7$ & $17.5 \pm 1.7$ & 0.294 \\
FO & $22.6 \pm 1.9$ & $21.7 \pm 1.7$ & $\mathbf{0 . 0 1 6}$ \\
FS & $30.9 \pm 2.3$ & $29.5 \pm 1.9$ & $\mathbf{0 . 0 0 2}$ \\
CC & $9.1 \pm 1.2$ & $8.5 \pm 1.1$ & $\mathbf{0 . 0 1 4}$ \\
FJ & $24.5 \pm 1.9$ & $23.0 \pm 2.0$ & $\mathbf{0 . 0 0 0}$ \\
OCn & $22.4 \pm 2.1$ & $22.5 \pm 2.1$ & 0.325 \\
\hline
\end{tabular}

$(\mathrm{P}<0.05)$
Table V. In males, the correlation of the obtained data.

\begin{tabular}{lcccc}
\hline & $\mathbf{H F}_{\text {ant }_{\text {er oposterior }}}$ & $\mathbf{H F}_{\text {height }}$ & $\mathbf{F M}_{\text {area }}$ & $\mathbf{F M}_{\text {trn }}$ \\
\cline { 2 - 5 } $\mathbf{F M}_{\text {sgt }}$ & $\mathbf{P}$ & $\mathbf{P}$ & $\mathbf{P}$ & $\mathbf{P}$ \\
\cline { 2 - 5 } $\mathbf{P}$ & 0.12 & -0.03 & 0.72 & 0.34 \\
$\mathbf{F M}_{\text {trn }}$ & $\mathbf{0 . 0 0 0}$ & $\mathbf{0 . 0 0 0}$ & $\mathbf{0 . 0 0 0}$ & $\mathbf{0 . 0 0 0}$ \\
$\mathbf{P}$ & -0.06 & -0.18 & 0.55 & --- \\
$\mathbf{F M}_{\text {area }}$ & $\mathbf{0 . 0 0 0}$ & $\mathbf{0 . 0 0 0}$ & $\mathbf{0 . 0 0 0}$ & --- \\
$\mathbf{P}$ & 0.13 & -0.09 & --- & --- \\
$\mathbf{H F}_{\text {height }}$ & $\mathbf{0 . 0 0 0}$ & $\mathbf{0 . 0 0 0}$ & --- & --- \\
$\mathbf{P}$ & 0.64 & --- & -- & -- \\
\hline$(\mathrm{P}<0.001)$ & $\mathbf{0 . 0 0 0}$ & --- & --- & --- \\
\hline
\end{tabular}

Table VI. In females, the correlation of the obtained data.

\begin{tabular}{lcccc}
\hline & $\mathbf{H F}_{\text {anter oposterior }}$ & $\mathbf{H F}_{\text {height }}$ & $\mathbf{F M}_{\mathbf{a}_{\text {rea }}}$ & $\mathbf{F M}_{\text {trn }}$ \\
\cline { 2 - 5 } & $\mathbf{P}$ & $\mathbf{P}$ & $\mathbf{P}$ & $\mathbf{P}$ \\
\cline { 2 - 5 } $\mathbf{F M}_{\text {sgt }}$ & 0.02 & -0.06 & 0.87 & 0.77 \\
$\mathbf{P}$ & $\mathbf{0 . 0 0 0}$ & $\mathbf{0 . 0 0 0}$ & $\mathbf{0 . 0 0 0}$ & $\mathbf{0 . 0 0 0}$ \\
$\mathbf{F M}_{\text {trn }}$ & 0.08 & -0.01 & 0.84 & --- \\
$\mathbf{P}$ & $\mathbf{0 . 0 0 0}$ & $\mathbf{0 . 0 0 0}$ & $\mathbf{0 . 0 0 0}$ & --- \\
$\mathbf{F M}_{\text {area }}$ & 0.10 & -0.01 & --- & --- \\
$\mathbf{P}$ & $\mathbf{0 . 0 0 0}$ & $\mathbf{0 . 0 0 0}$ & -- & -- \\
$\mathbf{H F}_{\mathbf{h}_{\text {eight }}}$ & 0.46 & --- & -- & --- \\
$\mathbf{P}$ & $\mathbf{0 . 0 0 0}$ & -- & --- & -- \\
\hline$(\mathrm{P}<0.001)$ & & & &
\end{tabular}

\section{DISCUSSION}

There were many important anatomic advantages of the present study, because of the measurements that can be made in living individuals, sex can be precisely identified, the number of cases can be increased, the detailed characteristics of bone and vascular structures can be revealed with high resolution, three-dimensional, and multislice images. Furthermore, this study is superior to dry bone studies because of precise sex discrimination, cadaveric studies because of minimal tissue shrinkage, the panoramic radiographic studies because of foramina, either could not be identified or indistinct, direct radiographic studies because of the magnification factor, ultrasonographic studies because of limited information for the identification of bony structures.

Skull base creates an interface with the complex anatomy providing the connection of neural and vascular structures between it and cranial fossae, paranasal sinuses, orbita, neck and supporting the intracranial formations. Skull base has always been popular and interesting for brain surgeon (Ziyal et al., 2002). Skull base fractures are observed in $3.5-24 \%$ of head trauma patients. The incidence of skull base fractures was related to the location of facial fractures. The frequency of skull base fractures is $25 \%$ in trauma 
patients who are seen for facial fractures. Dramatically, this ratio decreased to $2.9 \%$ in patients without facial fractures (Spluchynskyj et al., 1992). It may be suspected from skull base fractures if a patient has symptoms such as periorbital ecchymosis, blindness, anosmia, rhinorrhea, hemotimpanum, hearing loss, facial paralysis, strabismus, mastoid ecchymosis, and otorrhea (Bek \& Tasdemiroglu, 2002).

Ziyal et al., also emphazised the importance of the three elements for successful surgical outcomes in skull base surgery as well as the other surgery branches. These elements were the shortest and easiest approach, adequate surgical field, and surgeon's skills. It is undoubted that these items are an integral unity. In our opinion, the fourth element must be good anatomical knowledge and assessment of morphometric data.

The size and shape of sellae turcica (e.g. AxenfeldRieger and Williams syndromes, racial differences, intrasellar adenomas, empty sella syndrome, Rathke's cleft cysts, Sheehan's syndrome) is highly variable (Swallow \& Osborn, 1998; Axelsson et al., 2004). The evaluation of the sellae turcica is very important in terms of cranial morphology, growth changes and the review of the success rate of the orthodontic treatment results (Axelsson et al.). Alkofide (2007) assessed the dimensions of the sellae turcica of 180 (90 male - 90 female) (11-26 years old) individuals belonging to different skeletal types. In males, the anteroposterior length and height of the sellae turcica were reported $11.0 \mathrm{~mm}$ and $9.1 \mathrm{~mm}$ and in females, their measurements were $10.7 \mathrm{~mm}$ and $9.1 \mathrm{~mm}$, respectively. Axelsson et al. observed that the height and diameter increased with age, but the anteroposterior length was constant in Norwegians. Lang (2001) detected that the anteroposterior length and height were $10.69 \mathrm{~mm}$ and 6.85 $\mathrm{mm}$, respectively. The present study, these data were 10.1 $\mathrm{mm}$ and $9.3 \mathrm{~mm}$ in males, $10.2 \mathrm{~mm}$ and $9.5 \mathrm{~mm}$ in females, respectively (Table II). It was noteworthy that the hypophysial fossa was deeper.

Lang has been reported that the distances between tuberculum sellae and foramen caecum, tuberculum sellae and prechiasmatic sulcus, tuberculum sellae and dorsum sellae were $42.57 \mathrm{~mm}, 6.80 \mathrm{~mm}$, and $10.76 \mathrm{~mm}$, respectively. In our study, these data were $47.5 \mathrm{~mm}, 8.7 \mathrm{~mm}$, and 10.7 $\mathrm{mm}$ in males, $46.9 \mathrm{~mm}, 8.3 \mathrm{~mm}$, and $10.2 \mathrm{~mm}$ in females, respectively (Table II). Although our study results were higher than Lang's results, the distance between tuberculum sellae and dorsum sellae was conformed.

Clivus is a complex structure with deep localization which provides mechanical support for brain stem, cranial nerves and vascular structures. Tumors which were located on the clivus and reliable, less invasive, effective surgical approaches (sublabial transnasal approach, posterior cranial fossa route) applied to these tumors were reported (Nakao \& Itakura, 2007). The transverse, longitudinal and oblique fractures of clivus may especially, suggest symptoms such as isolated cranial nerve palsies (II, III, IV, V, VI, VII cranial nerves), rhinorrhea, otorrhea, pituitary dysfunction, and intracranial clinical manifestations due to vascular injury in patients with severe head trauma (Menkü et al., 2004; Paterakis et al., 2005). The distance between dorsum sellae and anterior margin of the foramen magnum which reflects length of clivus was identified as $45 \mathrm{~mm}$ by Lang. In our study, this distance was $49.2 \mathrm{~mm}$ in males, $46.4 \mathrm{~mm}$ in females (Table II).

The most important content of the optic canal is the optic nerve along with meninges and the ophthalmic artery inferolaterally embedded within the dura mater (Choudhry et al., 2005). The optic nerve can be injured after head trauma or decompressed with optic nerve meningioma. The involvement of optic canal is a common clinical entity due to tuberculum sellae and clinoidal meningiomas (Sade \& Lee, 2009). Knowledge of the dimensions of the optic canal and adjacent bony structures may be helpful in performing surgical exploration of the canal for its decompression, removal of tumor, or approaches to the cavernous sinus or sella (Slavin et al., 1994). Lang reported as $14.0 \mathrm{~mm}$ the distance between right and left optic canal. In our study, the distance was $18.4 \mathrm{~mm}$ in males, $18.0 \mathrm{~mm}$ in females (Table I). The distance between the anterior clinoids was $25.67 \mathrm{~mm}$ in literature (Slavin et al.). In this study, the distance was also $27.3 \mathrm{~mm}$ in males, $25.6 \mathrm{~mm}$ in females (Table II).

The data of bony structures according to midline could helpful if surgical dissection in middle cranial fossa is warranted. The trigeminal neuralgia can be treated by direct access to the foramen ovale or rotundum. The different tumours such as meningioma, schwannomas and chordomas may appear in cavernous sinus region and percutaneous biopsy of cavernous sinus tumour may perform for example through the foramen ovale (Yi et al., 2009). Lang determined as $16.5 \mathrm{~mm}$ the distance from left foramen rotundum to the midline on the internal skull base. In the present study, the right and left distances were $19.4 \mathrm{~mm}$ and $18.8 \mathrm{~mm}$ in males, $17.9 \mathrm{~mm}$ and $17.5 \mathrm{~mm}$ in females (Table I) and Lang's data were higher. The distance between right and left foramen ovale was measured as $44.5 \mathrm{~mm}$ (approximately the distance to the midline $22.25 \mathrm{~mm}$ ) on the external skull base (Lang). Whereas the distance from the left foramen ovale to the midline was $20.9 \mathrm{~mm}$ on the internal skull base. The data differences drew attention between external and internal faces. In our study, these distances were $46.1 \mathrm{~mm}$ (right 23.5 $\mathrm{mm}$, left $22.6 \mathrm{~mm}$ ) in males, $44.3 \mathrm{~mm}$ (right $22.6 \mathrm{~mm}$, left 
$21.7 \mathrm{~mm}$ ) on the internal skull base in females (Table I). The results were slightly higher according to Lang's data. Also reported that the distance between right and left foramen spinosum was $57.0 \mathrm{~mm}$ on the external skull base. In the present study, this distance were $62.9 \mathrm{~mm}$ (right 32.3 $\mathrm{mm}$, left $30.6 \mathrm{~mm}$ ) in males, $60.4 \mathrm{~mm}$ (right $3.09 \mathrm{~mm}$, left $29.5 \mathrm{~mm}$ ) in females (Table I). We thought that the reasons of the differences between the results was because of the different measurement points on the internal skull base or racially different structures of the head due to craniosynostosis.

The carotid canal, tympanic cavity and cochlea were the adjacent structures each other. Therefore, it is important the distance from carotid canal to midline. The distance between the right and left carotid canal apertura was obtained $49.1 \mathrm{~mm}$ on the external skull base by Lang. In our study, the distance between right and left internal apertura of the carotid canal was $18.1 \mathrm{~mm}$ (right $9.1 \mathrm{~mm}$, left $9.0 \mathrm{~mm}$ ) for males, $17.6 \mathrm{~mm}$ (right $9.1 \mathrm{~mm}$, left $8.5 \mathrm{~mm}$ ) for females (Table I).

Lang reported that the distance between right and left porus acusticus internus was $57.13 \mathrm{~mm}$. In our study, this distance for males and females was $48.2 \mathrm{~mm}$ and 45.8 $\mathrm{mm}$, respectively (Table II).

The jugular foramen is very important apertura which are include the portions of the glossopharyngeal, vagal, accessory nerves and internal jugular vein. Lang observed that the distance between right and left foramen jugulare was $42.7 \mathrm{~mm}$ on the external skull base and $41.3 \mathrm{~mm}$ on the internal skull base. In our study, the distance was $51.6 \mathrm{~mm}$ (right $26.3 \mathrm{~mm}$, left $25.3 \mathrm{~mm}$ ) for males, $47.5 \mathrm{~mm}$ (right $24.5 \mathrm{~mm}$, left $23.0 \mathrm{~mm}$ ) for females on the internal skull base (Table I).

There were the detailed anatomical studies which the sizes and variations of the hypoglossal canal were examined (Karasu et al., 2009). The distance between the right and left hypoglossal canal was detected as $27.8 \mathrm{~mm}$ by Lang. In this study, in males and females, the distance was $28.6 \mathrm{~mm}$ and $27.2 \mathrm{~mm}$, respectively (Table II). It was observed that the results of both studies were compatible.

In recent years, it has been reported in many cases that the fractures of occipital condylus were detected with the advancement of MDCT (Tuli et al., 1997). The shape, length, and width of the occipital condylus should be radiologically analyzed in patients who will undergo operation on craniovertebral junction (Naderi et al., 2005). The knowledge of the anatomical data is extremely important to make the reliable resection of the occipital condylus at the transcondylar, paracondylar, and supracondylar surgical approaches (Rhoton, 2000). In 202 dry bones, the length, width, and height of the occipital condylus have been established as $23.4 \mathrm{~mm}, 10.6 \mathrm{~mm}$, and $9.2 \mathrm{~mm}$, respectively (Naderi et al.). The anterior and posterior intercondylar distances have been reported as 19.8 $\mathrm{mm}$ and $36.9 \mathrm{~mm}$, respectively. The occipital condylus resection approximately $12 \mathrm{~mm}$ does not damage neural structures. The length of the occipital condylus, the anterior and posterior intercondylar distances were $22.9 \mathrm{~mm}$, $23.6 \mathrm{~mm}$ and $42.1 \mathrm{~mm}$, respectively by Lang. Barut et al. reported that the anteroposterior length of the right and left occipital condylus were $23.3 \mathrm{~mm}$ and $22.9 \mathrm{~mm}$, respectively. In addition to, the distance between the anterior borders of the occipital condyles was $19.8 \mathrm{~mm}$ and the distance between the posterior borders was also $36.9 \mathrm{~mm}$. Naderi et al. reported that the length of the occipital condyle was $23.42 \mathrm{~mm}$ and the anterior and posterior intercondylar distances were 21.0 and $41.6 \mathrm{~mm}$, respectively. In the present study, length of the right and left occipital condylus, the anterior and posterior intercondylar distances were 24.5 $\mathrm{mm}$ and $24.6 \mathrm{~mm}, 19.0 \mathrm{~mm}$ and $40.5 \mathrm{~mm}$ in males, 22.4 $\mathrm{mm}$ and $22.5 \mathrm{~mm}, 17.7 \mathrm{~mm}$ and $39.1 \mathrm{~mm}$ in females, respectively (Tables I and II). The present study results were consistent with those in literature.

Morphometry of the foramen magnum region is essential for the transcondylar approaches or its variants (Muthukumar et al., 2005; Pereira et al., 2012). The treatment of the foramen magnum tumors is substantially discussed because of the location of vital vascular and neural structures. The foramen magnum tumors can be radically removed with successful surgery after careful and detailed preoperative evaluation. Therefore, knowledge of anatomy and biomechanics of this region is extremely important. There are anterior, posterior/posterolateral and lateral approach alternatives for the pathologies of foramen magnum according to localization of the tumour (Rhoton).

The sex determination of the adult human skeleton is important in anthropology and forensic sciences. In males and females, the area of foramen magnum was 909.91 $\mathrm{mm}^{2}$ and $819.01 \mathrm{~mm}^{2}$, respectively and the significant difference was between sexes. But, the correlation coefficient was lower, the important marker did not be the foramen magnum area for sex discrimination and it should be used along with other data (Günay \& Altinkök, 2000). In another study (Murshed et al., 2003), the area of foramen magnum was detected as $931.7 \mathrm{~mm}^{2}$ for males and $795.0 \mathrm{~mm}^{2}$ for females. These data were significantly different $(\mathrm{P}<0.001)$ and the significant correlation was also between size and area (Murshed et al., 2003). In our study, the area was $861 \mathrm{~mm}^{2}$ for males and $770 \mathrm{~mm}^{2}$ for females. 
The sagittal and transvers diameters were indicated 35.33 $\mathrm{mm}$ and $29.67 \mathrm{~mm}$ by Lang (2001). Murshed et al. observed on the 110 adult CT images that the sagittal and transvers diameters were $37.2 \mathrm{~mm}$ and $31.6 \mathrm{~mm}$ for males, $34.6 \mathrm{~mm}$ and $29.3 \mathrm{~mm}$ for females, respectively. In present study, these diameters were $36.8 \mathrm{~mm}$ and $30.9 \mathrm{~mm}$ for males, $34.6 \mathrm{~mm}$ and $29.7 \mathrm{~mm}$ for females (Table II).

The present study was the first anatomic study examined of skull base using MDCT. Differences were observed when the present study results were compared with data from the literature. The reasons could be the differences of the material, method, race, and measurement locations. In this study, we found the morphometric data (according to midline on skull base) of foramina that the important neurovascular structures passed. We believed that the morphometric measurements were reliable and the error rate was minimal according to the measurements on dry bones and direct radyographic images. Because, the data were obtained from living individuals and computer environment with MDCT. We think that the results of this study can be contributed to diagnosis and treatment in radiology and surgical branches, gender determination in forensic medicine, education in basic sciences.

GÖKCE, C.; CICEKCIBASI, A. E.; YILMAZ, M. T. \& KIRESI, D. Análisis morfométrico de las estructuras óseas importantes en base de cráneo de sujetos vivos mediante tomografía computarizada multidetector. Int. J. Morphol., 32(3):812-821, 2014.

RESUMEN: El objetivo de este estudio fue determinar datos morfométricos confiables de las estructuras óseas importantes de la base de cráneo mediante tomografía computarizada multidetector (TCMD) y establecer las diferencias de estos datos en función del sexo y lateralización. Se realizó un estudio retrospectivo a partir de imágenes de TCMD obtenidas en el Departamento de Radiología de la Facultad de Medicina Meram, Universidad de Necmettin Erbakan. Se evaluaron imágenes de 100 sujetos adultos (50 hombres y 50 mujeres), que no presentaban trauma craneal, cirugía o deformidad ósea. Se midieron (i) altura y diámetro anteroposterior de la fosa hipofisaria, (ii) longitud del cóndilo occipital y distancias intercondilares anterior y posterior, y (iii) el diámetro sagital, transversal y el área del foramen magno. El resumen de los datos se expresó como Media \pm DE. La comparación de los datos entre sexos y mediciones izquierda-derecha se realizó mediante la prueba t de Student, mientras que la relación entre los distintos parámetros mediante la prueba de correlación de Pearson. Todos los parámetros medidos, en el lado derecho e izquierdo, fueron mayores en hombres. Los valores más altos se determinaron generalmente en el lado derecho en ambos sexos. Algunos parámetros estuvieron altamente correlacionados en ambos sexos $(\mathrm{P}<0,001)$. Creemos que nuestros resultados pueden ser útiles al momento de realizar nuevos abordajes quirúrgicos y en la evaluación radiológica, relativas a la base de cráneo.

\section{PALABRAS CLAVE: Base de cráneo; Foramen; Canal; Morfometría; Tomografía computarizada multidetector.}

\section{REFERENCES}

Alkofide, E. A. The shape and size of the sella turcica in skeletal Class I, Class II, and Class III Saudi subjects. Eur. J. Orthod., 29(5):457-63, 2007.

Axelsson, S.; Storhaug, K. \& Kjaer, I. Post-natal size and morphology of the sella turcica. Longitudinal cephalometric standards for Norwegians between 6 and 21 years of age. Eur. J. Orthod., 26(6):597-604, 2004.

Barut, N.; Kale, A.; Turan Suslu, H.; Ozturk, A.; Bozbuga, M. \& Sahinoglu, K. Evaluation of the bony landmarks in transcondylar approach. Br. J. Neurosurg., 23(3):276-81, 2009.

Bek, S. \& Tasdemiroglu, E. Kafa tabanı kırıklarında sınıflandırma ve yaklasım (I. Bölüm). Türk Nöros sirürji Dergisi, 12(3):189202, 2002.

Choudhry, S.; Kalra, S.; Choudhry, R.; Choudhry, R.; Tuli, A. \& Kalra, N. Unusual features associated with cranial openings of optic canal in dry adult human skulls. Surg. Radiol. Anat., 27(5):455-8, 2005.
Cornu, P.; Hentati, K.; Chabolle, F.; Zouaoui, A.; Tamisier, D.; Hidden, G. \& Philippon, J. Lateral approach to the foramen magnum. Surg. Radiol. Anat., 12(1):77-8, 1990.

D'Aloisio, D. \& Pangrazio-Kulbersh, V. A comparative and correlational study of the cranial base in North American blacks. Am. J. Orthod. Dentofacial Orthop., 102(5):449-55, 1992.

George, B. \& Lot, G. Anterolateral and posterolateral approaches to the foramen magnum: technical description and experience from 97 cases. Skull Base Surg., 5(1):9-19, 1995.

Günay, Y. \& Altinkök, M. The value of the size of foramen magnum in sex determination. J. Clin. Forensic. Med., 7(3):147-9, 2000.

Karasu, A.; Cansever, T.; Batay, F.; Sabanci, P. A. \& Al-Mefty, O. The microsurgical anatomy of the hypoglossal canal. Surg. Radiol. Anat., 31(5):363-7, 2009. 
Lang, J. Skull base and related structures: Atlas of clinical anatomy. 2nd ed. Stuttgart, Schattauer Verlag, 2001.

Menkü, A.; Koç, R. K.; Tucer, B.; Durak, A. C. \& Akdemir, H. Clivus fractures: clinical presentations and courses. Neurosurg. Rev., 27(3):194-8, 2004.

Murshed, K. A.; Cicekcibas1, A. E. \& Tuncer, I. Morphometric evaluation of the foramen magnum and variations in its shape: A study on computerized tomographic images of normal adults. Turk. J. Med. Sci., 33(5):301-6, 2003.

Muthukumar, N.; Swaminathan, R.; Venkatesh, G. \& Bhanumathy, S. P. A morphometric analysis of the foramen magnum region as it relates to the transcondylar approach. Acta Neurochir. (Wien.), 147(8):889-95, 2005.

Naderi, S.; Korman, E.; Citak, G.; Güvencer, M.; Arman, C.; Senoglu, M.; Tetik, S. \& Arda, M. N. Morphometric analysis of human occipital condyle. Clin. Neurol. Neurosurg., 107(3):191-9, 2005

Nakao, N. \& Itakura, T. Sublabial transnasal approach combined with a partial resection of the nasal floor for midline skull base tumors. J. Clin. Neurosci., 14(3):267-72, 2007.

Paterakis, K. N.; Karantanas, A. H.; Hadjigeorgiou, G. M.; Anagnostopoulos, V. \& Karavelis, A. Retroclival epidural hematoma secondary to a longitudinal clivus fracture. Clin. Neurol. Neurosurg., 108(1):67-72, 2005.

Pereira, G. A. M.; Lopes, P. T. C.; Santos, A. M. P. V.; Duarte, R. D.; Piva, L. \& Pozzobon, A. Morphometric Analysis Related to the Transcondylar Approach in Dry Skulls and Computed Tomography. Int. J. Morphol., 30(2):399-404, 2012.

Prokop, M. Multislice CT angiography. Eur. J. Radiol., 36(2):8696, 2000

Rhoton, A. L. Jr. The far-lateral approach and its transcondylar, supracondylar, and paracondylar extensions. Neurosurgery, 47(3 Suppl.):S195-209, 2000.

Sade, B. \& Lee, J. H. High incidence of optic canal involvement in tuberculum sellae meningiomas: rationale for aggressive skull base approach. Surg. Neurol., 72(2):118-23, 2009.

Schwaber, M. K.; Netterville, J. L. \& Maciunas, R. Microsurgical anatomy of the lower skullbase--a morphometric analysis. Am. J. Otol., 11(6):401-5, 1990.

Slavin, K. V.; Dujovny, M.; Soeira, G. \& Ausman, J. I. Optic canal: microanatomic study. Skull Base Surg., 4(3):136-44, 1994.

Spluchynskyj, O. S.; Berkower, A. S.; Byrne, D. W. \& Cayten, C. G. Association of skull base and facial fractures. Laryngoscope, 102(11):1247-50, 1992.
Swallow, C. E. \& Osborn, A. G. Imaging of sella and parasellar disease. Semin. Ultrasound C.T. M.R., 19(3):257-71, 1998.

Tuli, S.; Tator, C. H.; Fehlings, M. G. \& Mackay, M. Occipital condyle fractures. Neurosurgery, 41(2):368-77, 1997.

Turhan-Haktanir, N.; Ayçiçek, A.; Haktanir, A. \& Demir, Y. Variations of supraorbital foramina in living subjects evaluated with multidetector computed tomography. Head Neck, 30(9):1211-5, 2008.

Ulug, T.; Ozturk, A. \& Sahinoglu, K. A multipurpose landmark for skull-base surgery: Henle's spine. J. Laryngol. Otol., 119(11):856-61, 2005.

Villavicencio, A. T.; Leveque, J. C.; Bulsara, K. R.; Friedman, A. H. \& Gray, L. Three-dimensional computed tomographic cranial base measurements for improvement of surgical approaches to the petrous carotid artery and apex regions. Neurosurgery, 49(2):342-52, 2001.

Yi, W.; Ohman, K.; Brännström, T. \& Bergenheim, A. T. Percutaneous biopsy of cavernous sinus tumour via the foramen ovale. Acta Neurochir. (Wien), 151(4):401-7, 2009.

Ziyal, I'. M.; Özcan, O. E. \& Özgen, T. Kafa tabanı cerrahisine genel bakıs. Türk Nörosirurji Dergisi, 12(2):101-14, 2002.

Correspondence to:

Aynur Emine Cicekcibasi, MD.

Department of Anatomy

Meram Medical Faculty,

Necmettin Erbakan University

42080 Meram, Konya

TURKEY

Email: aynurcicekcibasi@yahoo.com.tr

Received: 05-01-2014

Accepted: 23-06-2014 